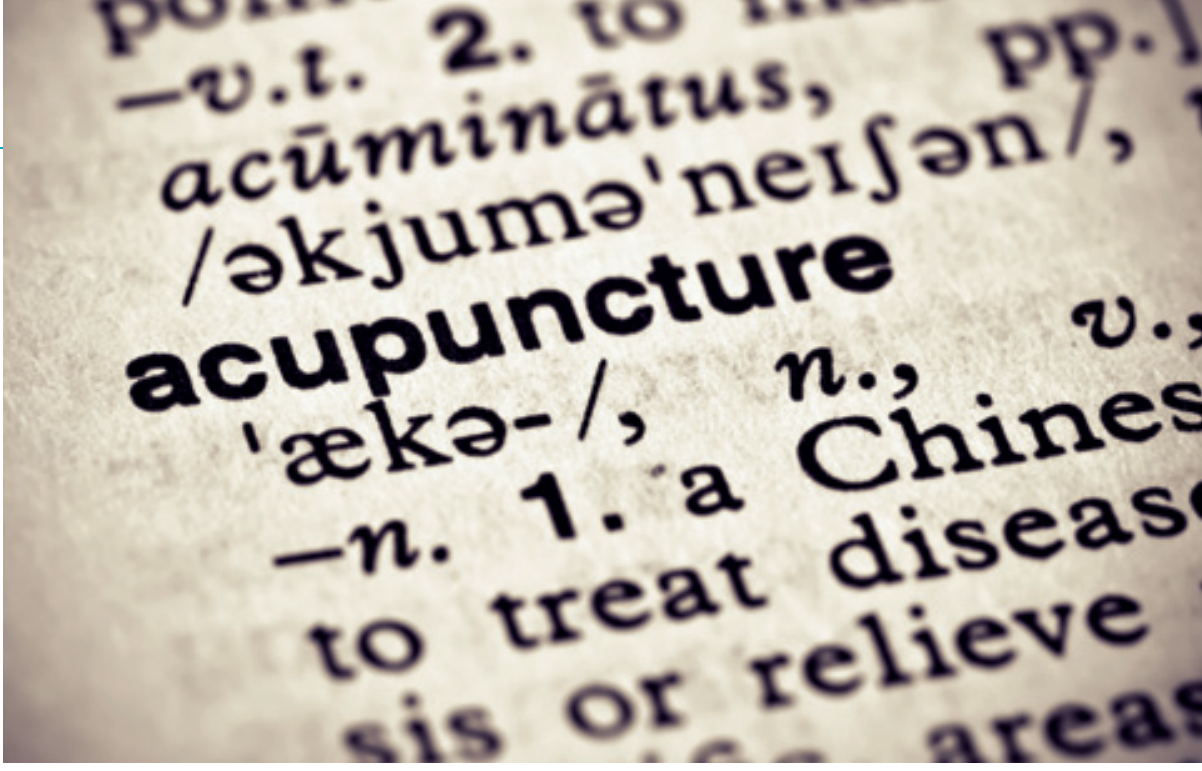

\title{
Mange sykehus tilbyr alternativ behandling
}

\section{Stadig flere sykehus i Norge og \\ Danmark tilbyr pasienter alternativ behandling.}

I 2001 ble alternativmedisinsk behandling tilbudt ved om lag hvert fjerde norske sykehus (1). I en ny studie viser vi nå at andelen er økt til $50 \%$ (2). Sykehusene tilbyr behandlingsformer som akupunktur, biofeedback, hypnose, kopping, øreakupunktur, urtemedisin, kunstterapi, homøopati, refleksologi, tankefeltterapi, gestaltterapi, aromaterapi, tai chi, akupressur, yoga, pilates etc. Tilsvarende studier fra Danmark viser at en tredel av sykehusene der tilbyr alternativ behandling, hovedsakelig akupunktur.

I Danmark anføres vitenskapelig evidens for effekt som hovedgrunn for å tilby akupunktur. I Norge er akupunktur oftest innført av sykehusledelsen, og vitenskapelig evidens anføres som grunn oftere i studien fra 2001. For de andre terapiformene oppgis den ansattes interesse for terapiformen som grunnlag for at pasienter tilbys behandlingen.

Studien er basert på den øverste medisinske ansvarliges definisjon av alternativ behandling og vedkommendes oversikt over aktiviteter som foregår på sykehusavdelingene. Over halvparten av kontaktpersonene anga at de ikke anså behandlingsformen som alternativ behandling.
Laila J. Salomonsen
laila.salomonsen@uit.no
Nasjonalt forskningssenter innen komplementær og alternativ medisin
Universitetet i Troms $\varnothing$
Litteratur
1. Salomonsen LJ, Skovgaard L, la Cour S et al. Use of complementary and alternative treatment in Norwegian and Danish hospitals. BMC Comple- ment Altern Med 2011; 11: 4
2. Salomonsen LJ, Grimsgaard S, Fønnebø V. Bruk av alternativmedisinsk behandling ved norske syke- hus. Tidsskr Nor Lægeforen 2003; 123: 631 -3.

\section{Intraperitoneal infeksjon} ved laparoskopisk appendektomi

Det er velkjent at laparoskopisk appendektomi er forbundet med lavere risiko for sårinfeksjon enn åpen kirurgi, men det er $\emptyset$ kt risiko for intraperitoneal infeksjon (Ann Surg 2010; 252: 895-900).

I et amerikansk nasjonalt register ble det identifisert nesten 40000 pasienter som hadde fått foretatt appendektomi i tidsrommet 2005-08. Forskerne undersøkte faktorer relatert til pasientene, operasjonen og antallet av sårinfeksjoner/ intraperitoneale infeksjoner. $77 \%$ av appendektomiene var laparoskopiske.

Det var lavere risiko for sårinfeksjon ved laparoskopi (OR 0,37). Men etter justering for konfunderende faktorer var det $ø \mathrm{kt}$ risiko for intraperitoneal infeksjon (OR 1,44). Man så forhøyet risiko for menn, røykere og pasienter med preoperativ sepsis samt ved operasjonstid over én time.

\section{Risiko for selvmord etter hjerteinfarkt}

Der er økt risiko for selvmord etter et akutt myokardinfarkt, særlig for personer med tidligere psykiatrisk lidelse (Circulation 2010; 122: 2388-93). Dette er konklusjonen i en populasjonsbasert pasient-kontrollstudie fra Danmark. I perioden 1981-2006 døde nesten 20000 personer i alderen 40-89 år i selvmord.

Risikoen for selvmord var høyest i den første måneden etter utskrivelse for myokardinfarkt. For pasienter uten tidligere psykiatrisk lidelse var det tre ganger økt risiko (RR 3,25), sammenliknet med personer uten tidligere infarkt. Risikoen var høyest for personer i alderen 40-49 år. Selv om risikoen var høyest i den første måneden etter infarktet var det fortsatt $\emptyset k t$ risiko i minst fem etterfølgende år.

\section{Global helsekonvensjon kan hjelpe verdens fattige}

\section{Helsetilstanden til verdens fattigste kan avhjelpes gjennom en global helsekonvensjon.}

Det er klare svakheter i det eksisterende internasjonale rammeverket for å sikre helsen hos klodens mest marginaliserte befolkninger. Det gjelder mangler i den rettighetsbaserte tilnærmingen til helseutfordringer, særlig helse som menneskerettighet. Det kommer frem i en artikkel som er skrevet av Just Haffeld, Harald Siem og John-Arne Røttingen (1). Førsteforfatteren er medisinstudent og jurist, har en mastergrad $\mathrm{i}$ forhandling $\mathrm{og}$ konflikthåndtering $\mathrm{og}$ er forsker ved Georgetown University.

Forfatterne undersøker hvorvidt en global helsekonvensjon vil kunne være et egnet instrument for å håndtere noen av de mest fastlåste problemene innen global helse. Et overordnet globalt rammeverk for helserettigheter kan særlig bidra til å oppstille prinsipper for samarbeid, ansvarlighet og fordeling av ressurser mellom aktører. Det kan også bidra til å definere hva som menes med grunnleggende overlevelsesbehov, strukturere og koordinere finansiering av globale helseinvesteringer og gi regler for tilgang til helsetjenester, inkludert krav til nasjonale prioriteringer. Det er imidlertid store utfordringer knyttet til en helsekonvensjon, for eksempel internasjonal støtte til overnasjonale regler, fremforhandling av samarbeidsløsninger og å sikre WHOs støtte som samlingspunkt.
Artikkelen har vakt internasjonal oppmerksomhet. Et utkast ble drøftet av over 30 deltakere fra flere land i en samling i Helsedirektoratet. Diskusjonene endte opp i et initiativ for global helse, der sentrale aktører er aidsaktivisten Section 27 i Sør-Afrika, Georgetown University og Helsedirektoratet (2).

\section{Just Haffeld}

just.haffeld@studmed.uio.no

Universitetet i Oslo

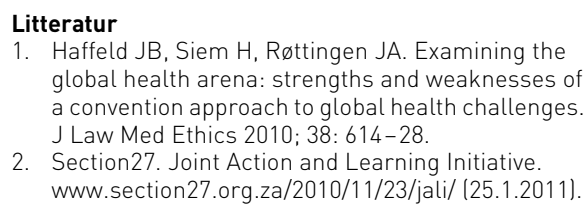

